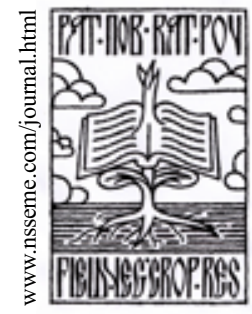

\title{
Influence of Harvest Dates on Sugar Beet Quantitative Traits
}

\author{
Živko Ćurčić • Dario Danojević • Nikola Čačić • \\ Nevena Nagl • Ksenija Taški-Ajduković • Lazar Kovačev
}

\author{
received: 15 November 2011, accepted: 9 February 2012. \\ (c) 2012 IFVC \\ doi:10.5937/ratpov49-1197
}

\begin{abstract}
Summary: Results of the investigation regarding influence of harvest dates on quantitative traits of sugar beet are presented in this paper. The three-year trial was conducted on five varieties developed by Institute of Field and Vegetable Crops, Novi Sad. Analysis of variance showed significant differences between harvest dates in 2008 and 2010 for all analyzed traits, but in 2009, due to severe drought differences were not found. With the delay of harvest date, root and raw sugar yield increased, while sugar content was dependent on climatic conditions (precipitation) between two harvest dates. There were no differences among the analyzed genotypes for measured traits in 2010. Interaction between genotype and harvest date has not been confirmed. Variety Drena had the highest root and raw sugar yields in 2008 and 2010.
\end{abstract}

Key words: genotypes, roots, harvesting dates, sugar beet, sugar content, sugar yield

\section{Introduction}

Sugar beet genotypes can significantly differ in root yield and quality, which are the traits under high influence of environment. According to Lüdecke (1953) sugar beet varieties can be divided into three types: $\mathrm{E}$ - high yield type, $\mathrm{Z}$ - sugar type and the transition between these two types $\mathrm{N}$ - normal type. In addition to the increased sugar content, $\mathrm{Z}$ - type varieties are characterized by better technological properties (low content of impurities) and earlier attainment of technological maturity.

Since sugar beet variety trials are usually harvested at the end of the growing period, information about effect of harvest date on yield and quality of sugar beet root can be very valuable. Previous studies (Oldemeyer et al. 1977, Lauer 1997, Čačić et al. 2000, Cakmakci \& Oral 2002, Jozefyová et al. 2003, Filipović et al. 2009) did not offer the full explanation about interaction between genotype and harvest date. One group of authors (Oldemeyer et al. 1977, Kerr 2000)

Ž. Ćurčić́* • D. Danojević • N. Čačić • N. Nagl • K. Taški-Ajduković - L. Kovačev

Institute of Field and Vegetable Crops, Maksima Gorkog 30, 21000

Novi Sad, Serbia

e-mail: zivko.curcic@ifvcns.ns.ac.rs determined the existence of significant interaction between genotype and harvest date for root yield, sugar content and sugar yield. In contrast to them, the other group (Lauer 1997, Bloch \& Hoffmann 2005, Heidari et al. 2008) considered that there is no interaction between genotype and harvest date and that all genotypes react similarly with the delay of harvest date.

In the last years, sugar beet harvesting campaign in Serbia starts at the end of August. Duration of campaign is dependent on climatic conditions and can last for more than three months. Having that in mind, the aim of this research was to determine influence of early harvest dates on sugar beet root yield and quality in five hybrid varieties.

\section{Materials and Methods}

Five commercially grown hybrid varieties of sugar beet from the Institute of Field and Vegetable Crops in Novi Sad were included in this trial, namely Lara, Drena, Darija, Irina and Vera. All of the tested varieties are resistant to rhizomania. Lara and Drena are the most common varieties in commercial production of the Institute.

Supported by Ministry of Education and Science of the Republic of Serbia, Project No. TR31015 
Lara achieves technological maturity in 150-160 days, has a high sugar content, good technological quality and is recommended for early harvest. Drena achieves full technological maturity in 160-180 days, belongs to normal-yield (NE) type of varieties and is recommended for middle and late harvest. Darija achieves full technological maturity in 180-200 days, belongs to high yield (E) type varieties and is recommended for late harvest (Kovačev et al. 2005). Hybrid variety Irina also belongs to high yield (E) type varieties and is recommended for late harvest (Kovačev et al. 2007). New variety Vera belongs to sugar (Z) type of varieties and is recommended for early and middle harvest date (Kovačev et al. 2011). The trial was conducted at the experimental field of Institute of Field and Vegetable Crops on Rimski Šančevi ( $\left.45^{\circ} 20^{\prime} \mathrm{N}, 19^{\circ} 51^{\prime} \mathrm{E}\right)$ in 2008, 2009 and 2010. It was established in a randomized block design with three replications, with the basic plot size of $30 \mathrm{~m}^{2}$. Sowing was performed in optimal time in the third decade of March. During the growing season were applied regular cultural practices for sugar beet. The total amount of nitrogen applied was $100 \mathrm{~kg}$ in $2008,133 \mathrm{~kg}$ in 2009 and $212 \mathrm{~kg}$ in 2010 year. The roots were harvested manually. Harvest dates were: 01 September, 16 September and 01 of October in all three years. Sugar content was determined in the Laboratory for root quality testing at the Institute of Field and Vegetable Crops, according to standard methodology.

Weather conditions were very different during the three growing seasons (Tab. 1). The average temperature during the vegetation was higher than the long term average. In the first two years there was lack of precipitation compared to the long term average. Distribution of precipitation in the first two years were very similar, until September, when in 2008 were recorded $93.6 \mathrm{~mm}$ precipitation and in 2009 only $13.1 \mathrm{~mm}$. Average temperature in July and August of 2009 were higher by $1^{\circ} \mathrm{C}$ and in September by $3.5^{\circ} \mathrm{C}$ comparing to 2008 . The lack of precipitation in these two years was reflected in reduced yields. In the third year of there was very high amount of precipitation, twice as much than 2008 and 2009. The difference in precipitation between the 2009 and 2010 was $412.1 \mathrm{~mm}$. Because of these weather conditions in 2010 there was a reduction in the quality of sugar beet roots.

All results were processed in the statistical software Statistica for Windows v. 10, Statsoft Inc. by ANOVA as two-factorial (genotype / harvest date) and three-factorial trial (genotypes / harvest date / year).

\section{Results and Discussion}

Because of the specific weather conditions during the study, such as severe drought in 2009 and heavy rainfall in 2010, yield and quality of sugar beet root extremely varied, and therefore the results of variance analysis varied between the years (Tab. 2).

Influence of harvest date on the measured traits was significant in the first and third years of study, while in 2009 those differences were not significant. This result is a direct consequence of severe drought in August and September of 2009. In those conditions there was a reduction in the phenotypic variation of studied traits, masking the genetic sources of variation (Ober et al. 2005). Effect of genotype also varied from year to year: there were differences between genotypes in 2008 for root yield and raw sugar yield, and in

Table 1. Weather conditions during the research period (2008-2010)

Tabela 1. Vremenski uslovi u godinama istraživanja (2008-2010)

\begin{tabular}{lcccccccc}
\hline & \multicolumn{4}{c}{$\begin{array}{c}\text { Rainfall }(\mathrm{mm}) \\
\text { Padavine }\end{array}$} & \multicolumn{4}{c}{$\begin{array}{c}\text { Average monthly temperature }\left({ }^{\circ} \mathrm{C}\right) \\
\text { Srednje mesečne temperature }\end{array}$} \\
\cline { 2 - 9 } & 2008 & 2009 & 2010 & $1964-2010$ & 2008 & 2009 & 2010 & $1964-2010$ \\
\hline April & 21.9 & 3.6 & 63.7 & 46.5 & 13.0 & 14.6 & 12.3 & 11.6 \\
May & 46.2 & 50.4 & 113.7 & 60.9 & 18.4 & 18.6 & 16.9 & 16.9 \\
Jun & 115.9 & 127.2 & 171.8 & 90.3 & 21.8 & 19.6 & 20.2 & 20.0 \\
July & 41.6 & 58.1 & 99 & 67.8 & 21.7 & 22.8 & 23.1 & 21.6 \\
August & 14 & 19.1 & 167.7 & 61.2 & 22.2 & 22.9 & 21.9 & 21.1 \\
15-September & 43.1 & 8.6 & 53.8 & & & & & \\
30-September & 50.5 & 4.5 & 13.9 & 46.7 & 15.7 & 19.2 & 16.1 & 16.8 \\
Total & 333.2 & 271.5 & 683.6 & 373.4 & - & - & - & - \\
Ukupno & & & - & - & 18.8 & 19.6 & 18.4 & 17.9 \\
Average & - & - & - & - & & & & \\
Prosek & & & & & & & &
\end{tabular}




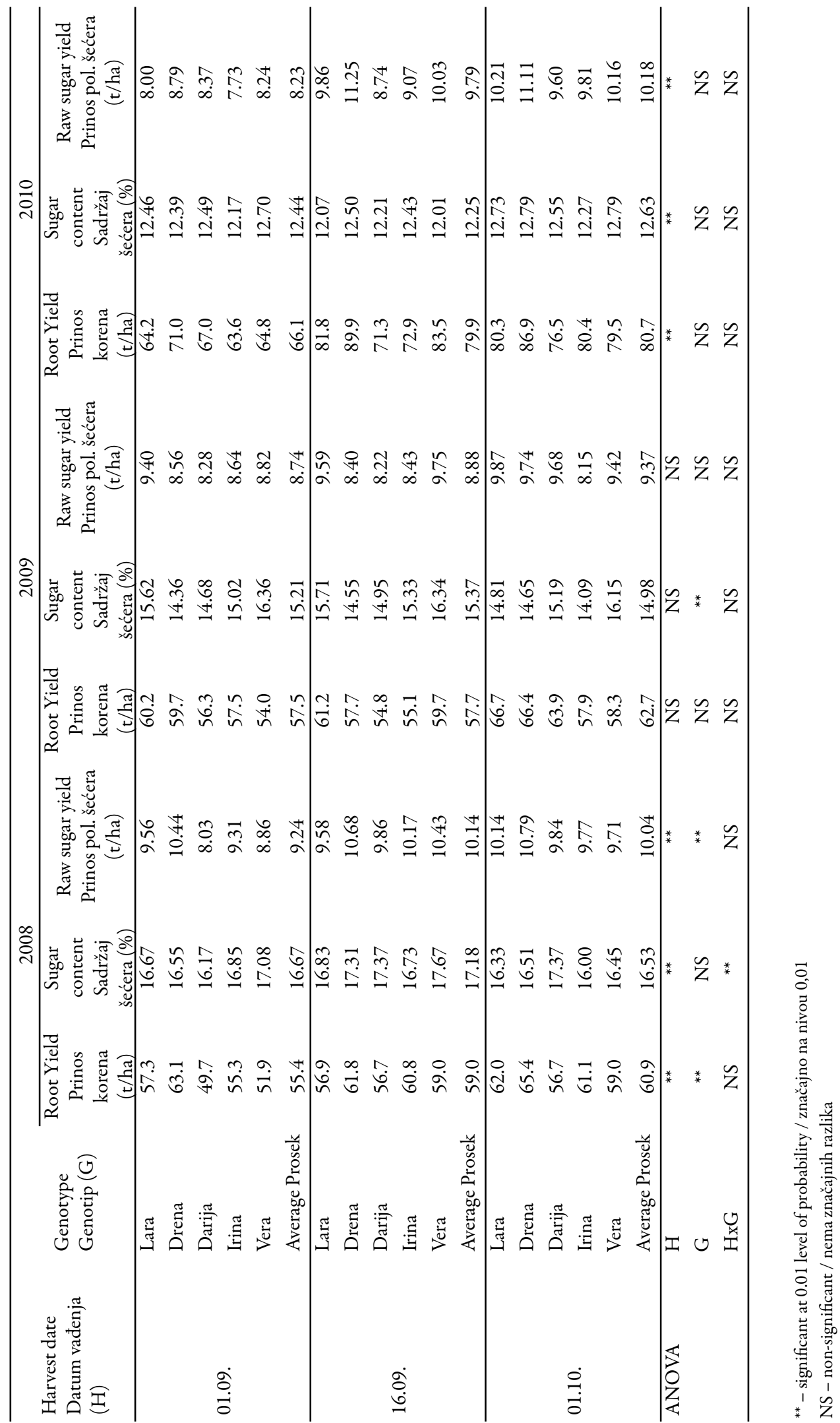


2009 only for sugar content. Interaction between genotype and harvest date was significant only for sugar content in 2008. In other years there was no interaction for all traits. These results are consistent with research of Lauer (1997), Eckhoff \& Bergman (1997) and Heidari et al. (2008), where the interaction between these two factors occurred sporadically and only for certain traits.

With the delay of harvest date, root yield increased during 2008 and 2010, as reported by Cakmaci \& Oral (2002), Jozefyová et al. (2003) and Filipović et al. (2009) (Tab. 2). Sugar content was under influence of weather conditions before harvest date. Because of the heavy rainfalls in September 2008 sugar content had lowest value in the last harvest date. In 2010 sugar content was lower by $4.35 \%$ compared to average in 2008 , and by $2.75 \%$ compared to 2009 . The most likely reason for this decline in sugar content is the combined impact of weather conditions (heavy rainfall) and the amount of applied nitrogen fertilizer $(212 \mathrm{~kg})$. Raw sugar yield increased with the delay of harvest date during 2008 and 2010. Average increase of raw sugar yield for three years of research between the first and last harvest dates was $1.13 \mathrm{tha}^{-1}$, which is consistent with result of Jozefyová et al. (2003), where average increase was $1.69 \mathrm{t} \mathrm{ha}^{-1}$ for 27 days.

Comparing varieties in 2008, variety Drena had the highest root yield and raw sugar yield in all three harvest dates (Tab. 2), confirming the results of Kovačev et al. (2004) about root yield in Drena. Significant differences between genotypes in sugar content were determined only in 2009 , and variety Vera had highest value, which was expected because it belongs to sugar $(Z)$ type of sugar beet varieties (Kovačev et al. 2011).

Results of analysis variance for three-factorial trial showed that effect of year, harvest date, genotype and interaction between year and harvest date were significant for all quantitative traits ( $T a b$. $3)$. Interaction between year and genotype was significant $(p<0.01)$ only for sugar content. Effect of interaction between genotype and harvest date was significant at level of probability 0.05 also for sugar content. According to Bloch \& Hoffmann (2005), Laidig (1994) claims that values of all interactions between genotype and environment in sugar beet are exceptionally low comparing to other field crops. Main reason for absence of interaction is that root and quantitative traits of root are estimated in commercial production of sugar beet. Root grows in vegetative phase of sugar beet development and in contrast to other field crops does not pass through sensitive stages like bolting, flowering, pollination and seed filling (Hoffmann et al. 2009). Although analysis of variance showed that effect of year was most important in total sum of squares for sugar content $(92.3 \%)$ and root yield (65.5\%) for raw sugar yield, effect of year was behind effect of harvest date and genotype effect. These results are consistent with those of Oldemeyer et al. (1977) who concluded that the harvest date had a greater effect on most studied traits than genotype.

Table 3. Results of analysis of variance, partitioning sums of squares (SS) and mean squares (MS) of the analyzed traits

Tabela 3. Analiza varijanse, učešće u sumi kvadrata (SS) i sredina kvadrata (MS) za ispitivana svojstva šećerne repe

\begin{tabular}{|c|c|c|c|c|c|c|c|c|c|c|}
\hline \multirow[b]{2}{*}{$\begin{array}{l}\text { Source of variation } \\
\text { Izvor varijacije }\end{array}$} & \multirow[b]{2}{*}{ DF } & \multicolumn{3}{|c|}{$\begin{array}{c}\text { Root yield } \\
\text { Prinos korena } \\
\end{array}$} & \multicolumn{3}{|c|}{$\begin{array}{l}\text { Sugar content } \\
\text { Sadržaj šećera }\end{array}$} & \multicolumn{3}{|c|}{$\begin{array}{c}\text { Raw sugar yield Prinos pol. } \\
\text { šećera }\end{array}$} \\
\hline & & SS (\%) & MS & F test & SS (\%) & MS & $F$ test & SS (\%) & MS & F test \\
\hline $\begin{array}{l}\text { Year }(\mathrm{Y}) \\
\text { Godina }\end{array}$ & 2 & 65.5 & 4182.2 & $86.8^{* *}$ & 92.3 & 215.41 & $992.9^{* *}$ & 13.8 & 7.11 & $7.90^{* *}$ \\
\hline $\begin{array}{l}\text { Harvest Date }(\mathrm{H}) \\
\text { Rok vađenja }\end{array}$ & 2 & 13.0 & 831.8 & $17.3^{* *}$ & 0.3 & 0.75 & $3.5^{*}$ & 29.8 & 15.40 & $17.10^{* *}$ \\
\hline $\begin{array}{l}\text { Genotype }(\mathrm{G}) \\
\text { Genotip }\end{array}$ & 4 & 7.7 & 246.0 & $5.1^{* *}$ & 1.6 & 1.90 & $8.8^{* *}$ & 18.6 & 4.82 & $5.35^{* *}$ \\
\hline $\mathrm{Y} / \mathrm{H}$ & 4 & 6.6 & 209.2 & $4.3^{* *}$ & 1.1 & 1.30 & $6.0^{* *}$ & 11.2 & 2.90 & $3.22^{*}$ \\
\hline $\mathrm{Y} / \mathrm{G}$ & 8 & 2.7 & 43.3 & 0.90 & 2.4 & 1.38 & $6.4^{* *}$ & 11.9 & 1.53 & 1.70 \\
\hline $\mathrm{H} / \mathrm{G}$ & 8 & 1.4 & 21.9 & 0.45 & 1.0 & 0.58 & $2.7^{*}$ & 4.6 & 0.59 & 0.65 \\
\hline $\mathrm{Y} / \mathrm{H} / \mathrm{G}$ & 16 & 3.2 & 25.3 & 0.53 & 1.3 & 0.37 & 1.7 & 10.1 & 0.66 & 0.73 \\
\hline $\begin{array}{l}\text { Error } \\
\text { Pogreška }\end{array}$ & 90 & - & 48.2 & & - & 0.22 & & - & 0.90 & \\
\hline
\end{tabular}

${ }^{*},{ }^{* *}$ - significant at 0.05 and 0.01 levels of probability / značajno na nivou 0,05 i 0,01 


\section{Conclusions}

Significant differences between harvest dates were determined for all measured traits (root yield, sugar content and raw sugar yield) in 2008 and 2010. With the delay of harvest date, root yield and raw sugar yield increased in 2008 and 2010. Sugar content was dependent on climatic conditions (precipitation) between two harvest dates. Heavy rainfall immediately before harvest date would lead to decrease of sugar content.

There were differences in root yield and raw sugar yield between genotypes in 2008 and in sugar content in 2009. In extremely wet 2010 there were no differences between genotypes. Variety Drena had the highest root yield and raw sugar yield in 2008 and 2010.

The research did not confirm interaction between harvest date and tested varieties. All genotypes had similar reaction in different harvest dates, so no particular genotype could be recommended for earlier or later harvest date.

\section{References}

Bloch D, Hoffmann C (2005): Seasonal development of genotypic differences in sugar beet (Beta vulgaris L.) and their interaction with water supply. J. Agron. \& Crop Sci. 191: 263-272

Cakmakci R, Oral E (2002): Root yield and quality of sugarbeet in relation to sowing date, plant population and harvesting date interactions. Turk. J. Agric. For. 26: 133-139

Čačić N, Kovačev L, Mezei S, Sklenar P, Nagl N (2000): Proces sazrevanja različitih tipova sorti šećerne repe. Selekcija i semenarstvo 7: 9-13

Eckhoff JLA, Bergman JW (1997): Influence of harvest date on sugar beet yield, quality, and economic return. Proc. Am. Soc. Sugar Beet Tech., Phoenix, 139-144
Filipović V, Glamočlija Đ, Radivojević S, Jaćimović G (2009): Uticaj gustine useva i rokova vađenja na prinos i kvalitet različitih sorti šećerne repe. Selekcija i semenarstvo 15: 45-53

Heidari G, Sohrabi Y, Esmailpoor B (2008): Influence of harvesting time on yield and yield components of sugar beet. J. Agri. Soc. Sci. 4: 69-73

Hoffmann C M, Huijbregts T, van Swaaij N, Jansen R (2009): Impact of different environments in Europe on yield and quality of sugar beet genotypes. Europ. J. Agron. 30: 17-26

Jozefyová L, Pulkrábek J, Urban J (2003): The influence of harvest date and crop treatment on the production of two different sugar beet variety types. Plant Soil Environ. 49: 492-498

Kerr S (2000): Variety interactions with sowing, soils and harvest. Br. Sugar Beet Rev. 68: 18-21

Kovačev L, Čačić N, Mezei S, Nagl N (2004): Produktivnost NS hibridnih sorti šećerne repe otpornih prema rizomaniji (BNYVV) u višegodišnjim ogledima. Zbornik radova Instituta za ratarstvo i povrtarstvo 40: 379-387

Kovačev L, Čačić N, Mezei S, Nagl N (2005): Značaj genetike, oplemenjivanja i genetičkog inženjeringa u povećanju potencijala rodnosti kod šećerne repe i produktivnost NS hibridnih sorti. Zbornik radova Instituta za ratarstvo i povrtarstvo 41: 35-50

Kovačev L, Čačić N, Mezei S, Stojaković Ž (2007): Produktivnost NS hibridnih sorti šećerne repe u dvogodišnjim multilokacijskim ogledima. Zbornik radova Instituta za ratarstvo i povrtarstvo 43: 161-167

Kovačev L, Čačić N, Mezei S (2011): Nove hibridne sorte šećerne repe Instituta za ratarstvo i povrtarstvo otporne prema rizomaniji. Ratar. Povrt. 48: 83-86

Lauer JG (1997): Sugar beet performance and interactions with planting date, genotype and harvest date. Agron. J. 89: $469-75$

Lüdecke H (1953): Zuckerrübenbau, ein Leitfaden für die Praxis. Paul Parey, Berlin

Ober ES, Bloa ML, Clark CJA, Royal A, Jaggard KW, Pidgeon JD (2005): Evaluation of physiological traits as indirect selection criteria for drought tolerance in sugar beet. Field Crops Res. 91: 268-279

Oldemeyer RK, Erichsen AW, Suzuki A (1977): Effect of harvest date on performance of sugar beet hybrids. J. Americ. Soc. Sugar Beet Technol. 19: 294-306

\title{
Uticaj rokova vađenja na kvantitativna svojstva šećerne repe
}

\author{
Živko Ćurčić • Dario Danojević • Nikola Čačić • \\ Nevena Nagl • Ksenija Taški-Ajduković • Lazar Kovačev
}

Izvod: U radu su predstavljeni rezultati trogodišnjeg ispitivanja uticaja tri roka vađenja šećerne repe na kvantitativna svojstva korena pet komercijalno gajenih sorata Instituta za ratarstvo i povrtarstvo u Novom Sadu. Analizom varijanse utvrđene su značajne razlike između rokova vađenja u 2008. i 2010. za sva ispitivana svojstva. Zbog suše u 2009. nisu utvrđene razlike između različitih datuma vađenja. Odlaganjem roka vađenja prinos korena i prinos polarizacionog šećera se linearno povećavao u 2008. i 2010. godini. Sadržaj šećera je varirao u zavisnosti od vremenskih uslova (padavine) između dva različita roka vađenja. U pogledu ispitivanih svojstava između genotipova nije uočena razlika samo u 2010. godini. Nije potvrđeno postojanje interakcije između genotipa i roka vađenja za ispitivana svojstva. Od ispitivanih sorata u 2008. i 2010. najbolja je bila sorta Drena, koja je u tim godinama ostvarila najveće prinose korena i polarizacionog šećera.

Ključne reči: genotip, koren, prinos šećera, rok vađenja, sadržaj šećera, šećerna repa 